\title{
Mengidentifikasi Peptida Bioaktif Angiotensin Converting Enzyme- inhibitor (ACEi) dari Kasein $\beta$ Susu Kambing dengan Polimorfismenya Melalui Teknik In Silico
}

\author{
Identification of Angiotensin Converting Enzyme-inhibitor (ACEi) Bioactive Peptide from Goat Milk $\beta$ - \\ Casein with It's Polymorphism by In Silico Technique \\ Hermawan Setyo Widodo ${ }^{1 *}$, Tridjoko Wisnu Murti ${ }^{2}$, Ali Agus ${ }^{2}$, Widodo ${ }^{2}$ \\ ${ }^{1}$ Fakultas Peternakan, Universitas Jenderal Soedirman, Purwokerto \\ ${ }^{2}$ Fakultas Peternakan, Universitas Gadjah Mada, Yogyakarta \\ *Korespondensi dengan penulis (hsw@unsoed.ac.id) \\ Artikel ini dikirim pada tanggal 28 Juli 2018 dan dinyatakan diterima tanggal 29 November 2018. Artikel ini juga dipublikasi secara online melalui \\ https://ejournal2.undip.ac.id/index.php/jatp. Hak cipta dilindungi undang-undang. Dilarang diperbanyak untuk tujuan komersial. \\ Diproduksi oleh Indonesian Food Technologists® @2018
}

\begin{abstract}
Abstrak
Susu kambing memiliki komponen protein salah satunya protein $\beta$ dan secara umum terjadi polimorfisme pada level protein. Perubahan urutan asam amino akibat polimorfisme memungkinkan adanya potensi dihasilkannya peptida bioaktif penghambat enzim pengubah angiotensin (ACEi). Penelitian ini bertujuan untuk menyaring peptida bioaktif yang berpotensi sebagai ACEi dari kasein $\beta$ kambing beserta polimorfismenya. Penelitian ini dilakukan dengan teknik in silico terhadap sekuen kasein $\beta$ kambing serta struktur tiga dimensi human testicular ACE. Langkah yang dilakukan dalam penelitian ini meliputi simulasi pemotongan peptida dengan enzim pencernaan (pepsin, tripsin dan kimotripsin), peninjauan karakteristik peptida lalu simulasi docking ligan-reseptor. Tampilan parameter Lipinski's Rule of Five (Ro5), bioaktivitas dan energi afinitas dipertimbangkan untuk memilih peptida bioaktif. Hasil yang didapat menunjukkan bahwa ditemukan peptida bioaktif yakni INK (Ile-Asp-Lys) yang memiliki kemampuan hampir setara dengan lisinopril (afinitas energi $-8,2 \mathrm{kkal} / \mathrm{mol}$ vs. $-8,3 \mathrm{kkal} / \mathrm{mol}$ ). Peptida INK dapat ditemukan dari hasil hidrolisis dari alel A, C, D dan E, sehingga polimorfisme tidak menyebabkan perbedaan produksi peptida bioaktif. Kesimpulan yang dapat diambil yakni kasein $\beta$ susu kambing jika dicerna dengan enzim pencernaan dapat menghasilkan peptida bioaktif ACEi yakni INK.
\end{abstract}

Kata kunci : susu kambing; ACEi; kasein $\beta$; peptida bioaktif; in silico

\section{Abstract}

Polymorphism eventually may be occurred at the protein level. Changes in the amino acid sequence due to polymorphism may exhibit a potential action to generate of the angiotensin-converting enzyme inhibitors (ACEi) bioactive peptide. This study is aimed to assess bioactive peptides that have a great potent value as ACEi from goat $\beta$ casein along with its polymorphism. The research was done by in silico technique on goat $\beta$-casein sequence and three-dimensional structure human testicular ACE. Peptide-cutting simulations with digestive enzymes (pepsin, trypsin and chymotrypsin), peptide properties review, then ligand-receptor docking simulations was applied in this research. Appearance of Lipinski's Rule of Five (Ro5), bioactivity and affinity energy were considered for selecting bioactive peptides. The results show that bioactive peptide found as INK (Ile-Asp-Lys) which had similar ability as lisinopril (energy affinity $-8.2 \mathrm{kcal} / \mathrm{mol} \mathrm{vs}$. $-8.3 \mathrm{kcal} / \mathrm{mol}$ ). The INK peptides could be found from the hydrolysis resulted in alleles $A, C, D$ and $E$, therefore polymorphism did not affect the differences of production of bioactive peptides. $A$ conclusion, processed goat milk $\beta$ casein with digestive enzymes could produce ACEi of INK as bioactive peptide.

Keywords : goat milk; ACEi; $\beta$ casein; bioactive peptides; in silico

\section{Pendahuluan}

Susu kambing dan susu jenis lainnya dari mamalia memiliki dua fraksi yakni kasein dan whey. Kasein ini terbagi menjadi beberapa fraksi yakni kasein $a_{\mathrm{s} 1}, \beta, a_{\mathrm{s} 2}$ dan $\mathrm{k}$ yang memiliki karakteristik khas dalam segi fisik dan kimiawinya (Park et al., 2007). Salah satu fraksi kasein yakni kasein $\beta$, diketahui sebagai sumber peptida bioaktif dalam susu kambing. Hal ini berkaitan dengan jumlah kasein $\beta$ sebanyak $30 \%$ dari seluruh protein susu atau $48 \%$ dari total kasein dan dinilai sebagai fraksi terbanyak dibandingkan kasein lainnya (Năsalean et al., 2017). Kasein $\beta$ jika ditelaah berdasarkan penyusunnya, terdiri dari 209 buah asam amino (aa) terbanyak diantaranya Glu, Pro, Leu serta sebagian besar berupa asam amino esensial sebanyak $50,3 \%$, sehingga memiliki berat molekul 23,82 $\mathrm{kDa}$ (Marletta et al., 2007; Salem et al., 2009). Salah satu bagian kasein $\beta$ memiliki sebutan "strategic zone" pada residu ke-60 sampai 70 karena memiliki manfaat $A C E i$, opioid dan imunostimulus (Haque and Chand, 2008). Hal tersebut menyebabkan susu kambing memiliki potensi sebagai sumber nutrisi yang baik serta menjadi bahan pangan fungsional bagi manusia karena menghasilkan peptida bioaktif yang berdampak positif pada kesehatan (Lee et al., 2005).

Kasein dalam susu dihasilkan melalui proses metabolisme protein di dalam sel sekretoris ambing sebagaimana terjadi pada organ lainnya (Marletta et al., 
2007). Gen penyandi kasein $\beta$ (CSN2) di dalam inti sel dibentuk salinan yang kemudian diterjemahkan menjadi rangkaian asam amino (Gao et al., 2017). Polimorfisme atau keragaman dapat terjadi pada gen CSN2. Hal tersebut terjadi akibat perubahan rangkaian sebuah atau beberapa asam nukleat baik berupa penyisipan, penghapusan, dan lainnya. Polimorfisme pada gen CSN2 kambing telah diketahui terdapat 7 alel yakni $A, B$, O, O', C, D dan E (Marletta et al., 2007) yang dapat menyebabkan perubahan rangkaian asam amino dan kemudian berdampak pada sifat protein berupa perubahan nilai titik isoelektrik bahkan menyebabkan nonsense stop codon (Caroli et al., 2006). Perubahan rangkaian asam amino karena polimorfisme dapat memberikan keuntungan yakni perbedaan fragmen peptida yang dihasilkan serta memiliki potensi sebagai peptida bioaktif dengan kemampuan berbeda, namun kajian mengenai hal tersebut, intensif pada susu sapi (Kaminski et al., 2007; Weimann et al., 2009; PetratMelin et al., 2015). Penelitian mengenai produksi peptida bioaktif akibat polimorfisme kasein $\beta$ susu kambing belum banyak dilakukan.

Peptida dari kasein susu kambing diketahui memiliki kemampuan menghambat enzim pengonversi angiotensin atau umum disebut sebagai Angiotensin Converting Enzym Inhibitor (ACEi). Enzim tersebut dapat mengakibatkan peningkatan tekanan darah atau hipertensi. Tekanan darah tinggi menyumbang 6,8\% kematian akibat penyakit tidak menular di Indonesia (Rahajeng dan Tuminah, 2009). Peptida penghambat ACE dapat dihasilkan melalui proses pemotongan oleh enzim pencernaan di lambung dan usus halus (Kaminski et al., 2007). Enzim pencerna yang dimaksud yakni pepsin, tripsin dan kimotripsin (Hermanto, 2016).

In silico menjadi salah satu metode terbaru yang mampu memprediksi suatu reaksi biokimia terjadi termasuk pencernaan protein. Metode tersebut menggunakan teknik bioinformatika dalam proses analisis yang dilakukan oleh peneliti sebelumnya (Muhammad and Fatimah, 2015). Metode in silico dalam penelitian ini memberikan simulasi pencernaan protein kasein $\beta$ susu kambing dengan polimorfismenya pada organ pencernaan manusia (Hermanto, 2016). Pemilihan fragmen peptida dapat dilakukan dengan parameter Lipinski's Rule of Five meliputi tampilan nilai berat molekul, LogP, donor dan akseptor hidrogen (Jedhe and Sanjayan, 2017). Parameter lain yakni bioaktivitas berupa protease inhibitor dan enzym inhibitor serta energi afinitas. Simulasi docking dapat digunakan untuk mempertimbangkan tingkat aktivitas ligan terhadap reseptor (Wang et al., 2011). Tujuan dari penelitian ini yakni menyaring peptida bioaktif yang berpotensi sebagai ACEi dari protein kasein $\beta$ berikut polimorfismenya melalui enzim pencernaan manusia. Enzim pepsin, tripsin dan kimotripsin dipilih agar menyerupai pencernaan protein susu kambing secara alami tanpa pengolahan (fermentasi dan koagulasi) terlebih dahulu, sehingga apabila ditemukan potensi peptida bioaktif ACEi dapat menjadi rujukan bahwa manfaat bahan pangan fungsional dapat diperoleh dengan mudah. Penelitian ini bertujuan untuk menyaring peptida bioaktif yang berpotensi sebagai ACEi dari kasein $\beta$ kambing beserta polimorfismenya yang dilakukan dengan teknik in silico terhadap sekuen kasein $\beta$ kambing serta struktur tiga dimensi human testicular ACE

\section{Materi dan Metode}

Penelitian ini menggunakan seperangkat komputer yang terkoneksi internet serta terinstal program luring pendukung teknik in silico diantaranya : Avogadro v1.2.0, Discovery Studio v17.2.0.16349 (Dassault Systemes Biovia Corp.), OSIRIS Data Warrior v4.7.2. (Idorsia Pharmaceuticals Ltd.), PyRx - Phyton Perscription 0.8 dan Microsoft Excel 2013 yang ditambahkan aplikasi pengolah statistik XLSTAT v2014.5.03 (Addinsoft). Program daring diantaranya : ExPASy-PeptideCutter (https://web.expasy.org/peptide_ cutter), National Center for Biotechnology Information (https://www.ncbi.nlm.nih.gov), Protein Data Bank RCSB (http://rcsb.org), serta Molinspiration yang diperoleh dari http://molinspiration.com. Sekuen kasein $\beta$ kambing (Capra hircus) didapat dari laman NCBI dengan kode akses AAA30906. Struktur tiga dimensi ACE diambil dari laman RSCB dengan kode akses 1086 yang berisi kompleks antara human testicular ACE dan lisinopril.

\section{Metode}

Keseluruhan metode penelitian merujuk pada Hermanto (2016) dengan beberapa modifikasi. Kajian dilaksanakan secara virtual menggunakan aplikasi komputer yang terhubung pada jaringan internet. Rangkaian metode secara umum yakni : (1) melakukan pemotongan secara virtual terhadap sekuen kasein $\beta$ dari tiap alel menggunakan enzim pencernaan serta ditabulasi fragmen yang terbentuk; (2) setiap fragmen tersebut disusun bentuk tiga dimensinya secara virtual agar didapatkan karakteristik struktur molekul salah satunya Lipinski's Ro5; (3) seleksi tiap bentuk tiga dimensi fragmen tersebut menjadi calon ligan melalui pengamatan kesamaan karakteristik molekul dengan lisinopril sebagai referensi melalui Principal Component Analysis; (4) percobaan penempelan ligan terpilih pada struktur ACE dan nilai yang muncul dibandingkan dengan referensi, sehingga didapat kemampuan hambatan kinerja ACE dari tiap ligan.

\section{Sintesis Ligan dari Kasein $\beta$ dan Polimorfismenya \\ Langkah penyusunan sekuen diawali dengan} membuka urutan asam amino dari hasil unduhan laman NCBI menggunakan aplikasi pengolah kata. Sekuen diedit secara manual untuk menentukan perubahan asam amino yang terjadi dari setiap alel berdasarkan referensi dari Marletta et al. (2009). Sekuen tiap alel kemudian dilakukan hidrolisis secara simultan menggunakan enzim pepsin, tripsin dan kimotripsin menggunakan ExPASy-PeptideCutter. Hasil hidrolisis berupa fragmen kode asam amino kemudian ditabulasi dan dilakukan transformasi menjadi struktur tiga dimensi menggunakan Avogadro. Struktur ligan tiga dimensi selanjutnya diminimalkan energinya dengan mode 
forcefield MMFF94 hingga tercapai nilai paling minimum, lalu disimpan dengan format dot pdb untuk dilakukan proses docking.

\section{Preparasi Struktur Enzim ACE}

Struktur tiga dimensi kompleks ACE dengan lisinopril perlu dipisahkan terlebih dahulu menggunakan aplikasi Discovery Studio. Molekul air dihapus terlebih dahulu kemudian lisinopril dipisahkan dari ACE sebagai sebuah ligan tersendiri dan disimpan dalam format dot pdb. Struktur tersebut kemudian dibuka kembali dengan Avogadro untuk dilakukan pengurangan hingga titik minimal energi.

Tabel 1. Karakteristik polimorfisme kasein $\beta$ kambing

No. Alel Karakteristik Jumlah pemotongan

\begin{tabular}{cccccc}
\hline 1. A Referensi dengan 207 buah & 34 & 15 & 32 & 81
\end{tabular} residu asam amino.

2. C Perubahan asam amino ke- $\begin{array}{lllll}34 & 15 & 32 & 81\end{array}$

177 dari Ala menjadi Val

3. D Perubahan asam amino $34 \quad 15 \quad 32 \quad 81$ ke177 dari Ala menjadi Val; ke-207 Val menjadi Asn

4. $\quad$ E Perubahan asam amino ke- $\begin{array}{llll}34 & 15 & 33 & 82\end{array}$ 166 dari Ser menjadi Tyr

Keterangan: $\mathrm{P}=$ Pepsin; $\mathrm{T}=$ Tripsin; $\mathrm{K}=$ Kimotripsin

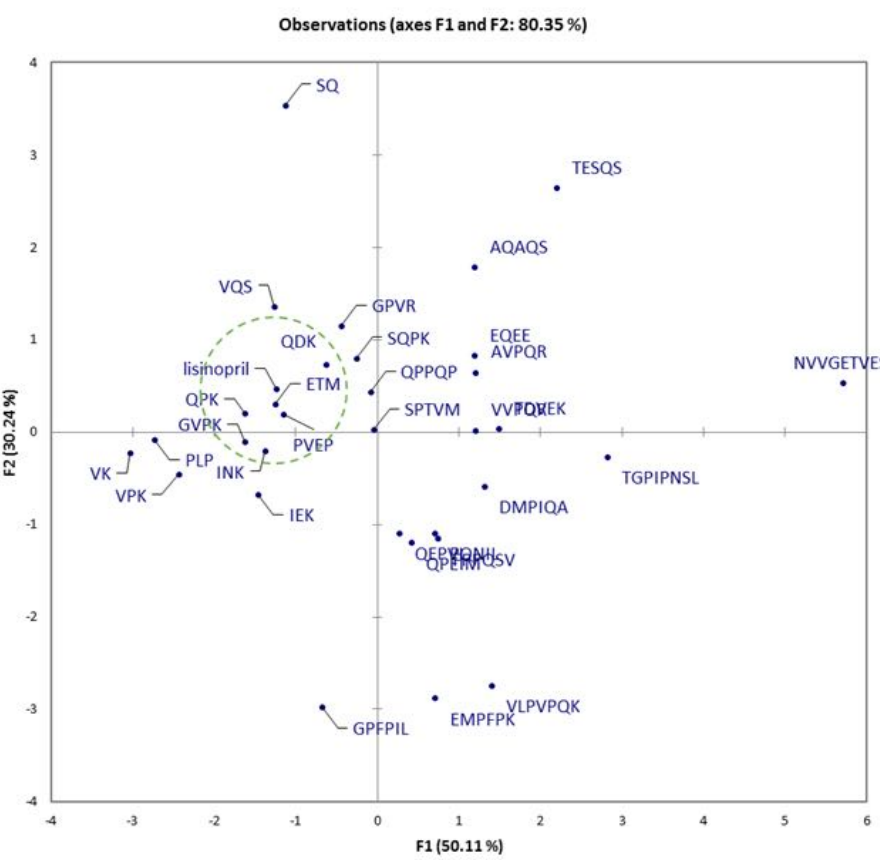

Figur 1. Hasil PCA antara peptida dengan Ro5

\section{Seleksi Ligan}

Ligan yang terkumpul berasal dari fragmen peptida dan lisinopril kemudian dihitung nilai Lipinski's Rule of Five/Ro5 (berat molekul, logP, donor hidrogen dan akseptor hidrogen) serta drug properties (mutagenic, tumorigenic, reproductive effective, drug likeness) menggunakan Osiris Data Warrior. Ligan yang terindikasi mengandung sifat berbahaya tidak dilanjutkan untuk proses selanjutnya. Data yang berisi Lipinski's Rule of Five kemudian ditabulasi pada aplikasi MS Excel dan dilakukan Principal Component Analysis
(PCA). Lisinopril sebagai kontrol positif dan peptida yang terdekat dengan lisinopril dipilih sebagai ligan kandidat untuk dilakukan proses docking. Nilai Bioactivity dihitung pula menggunakan Molinspiration.

\section{Simulasi Docking}

Proses simulasi docking dilakukan menggunakan aplikasi PyRx dengan protokol AutoDock Vina (Morris et al., 2008). Makromolekul yang dipilih yakni ACE serta ligan berupa peptida bioaktif terpilih dan lisinopril. Grid diatur sedemikian rupa agar mencakup ruang antara ligan dan makromolekul. Hasil berupa posisi pertautan terbaik dipilih berdasarkan nilai afinitas energi paling negatif. Hasil docking divisualkan dengan penggabungan antara file ligan yang memiliki nilai afinitas energi terbaik dengan ACE menggunakan aplikasi Discovery Studio. Bentuk dua dimensi divisualkan pula untuk mengetahui titik interaksi ligan dengan residu asam amino dari ACE. Semua data yang didapat diinterpretasikan secara deskriptif.

\section{Hasil dan Pembahasan}

Kasein $\beta$ memiliki keragaman pada level protein serta dapat diaplikasikan dalam kajian ini dengan jumlah 4 alel yakni A, C, D dan E. Alel O dan O' tidak diikutkan karena jumlah asam amino tidak lengkap dibandingkan dengan referensi. Alel B belum teridentifikasi karakteristik polimorfismenya (Marletta et al., 2007). Tiap alel tersebut memiliki karakteristik yang disajikan pada Tabel 1.

Enzim pepsin bekerja dengan maksimal pada $\mathrm{pH}$ 2,0 dengan menghidrolisis asam amino aromatik secara khusus pada bagian terminal-N (Johnston et al., 2007). Enzim tripsin bekerja dengan menghidrolisis ujung $\mathrm{C}$ dari asam amino lisin dan arginin, kecuali prolin, walaupun dalam beberapa penelitian asam amino tersebut terpotong pula (Rodriguez et al., 2008). Kimotripsin bekerja dengan menghidrolisis peptida pada ujung $\mathrm{N}$ yang mengandung residu triptofan, tirosin, fenilalanin atau leusin. Hasil hidrolisis dari kasein $\beta$ dan polimorfisme pada level protein oleh enzim pepsin, tripsin, dan kimotripsin menghasilkan rata-rata 82 fragmen dari 81 titik pemotongan tiap alel. Alel E terdapat perbedaan jumlah fragmen yakni 83 karena terjadi 82 titik pemotongan dan memungkinkan pembentukan peptida bioaktif lebih banyak. Data mengenai letak pemotongan peptida terpilih dan enzim pemotong tersaji pada Tabel 2 .

Tabel 2. Letak pemotongan peptida oleh enzim pencernaan

\begin{tabular}{lcc}
\hline $\begin{array}{c}\text { Nama } \\
\text { Molekul }\end{array}$ & $\begin{array}{c}\text { Posisi Residu } \\
\text { (asam amino ke- })\end{array}$ & Enzim Penghidrolisis \\
\hline ETM & $100-102$ & Kimotripsin \\
GVPK & $94-97$ & Tripsin \\
INK & $26-28$ & Tripsin \\
PVEP & $115-118$ & Pepsin \\
QDK & $46-48$ & Tripsin \\
QPK & $166-169$ & Tripsin \\
\hline
\end{tabular}

Keterangan: $\mathrm{D}=$ Aspartat; $\mathrm{E}=$ Glutamat; $\mathrm{G}=$ Glisin; I = Isoleusin; $\mathrm{K}=$ Lisin; $\mathrm{M}=$ Metionin; $\mathrm{N}$ = Asparagin; $\mathrm{P}=$ Prolin; $\mathrm{Q}$ : Glutamin; $\mathrm{T}=$ Threonin; $\mathrm{V}=$ Valin. 
Tabel 3. Tampilan karakteristik tiap ligan

\begin{tabular}{|c|c|c|c|c|c|c|c|}
\hline \multirow{2}{*}{ Nama Molekul } & \multicolumn{4}{|c|}{ Lipinski's Rule of Five (Ro5) } & \multicolumn{2}{|c|}{ Bioaktivitas } & \multirow{2}{*}{$\begin{array}{c}\text { Energi Afinitas } \\
(\mathrm{kkal} / \mathrm{mol})\end{array}$} \\
\hline & $\begin{array}{c}\text { Berat } \\
\text { Molekul (Da) }\end{array}$ & $\log P$ & Akseptor H & Donor $\mathrm{H}$ & $\begin{array}{l}\text { Protease } \\
\text { Inhibitor }\end{array}$ & $\begin{array}{l}\text { Enzyme } \\
\text { Inhibitor }\end{array}$ & \\
\hline ETM & 380,440 & $-2,2369$ & 10 & $6^{*}$ & 0,61 & 0,40 & $-8,0$ \\
\hline GVPK & 401,506 & $-1,0212$ & 10 & 5 & 0,72 & 0,29 & $-7,8$ \\
\hline INK & 375,468 & $-1,4868$ & 10 & $6^{*}$ & 0,65 & 0,30 & $-8,2$ \\
\hline PVEP & 441,503 & $-1,5594$ & $11^{*}$ & 5 & 0,75 & 0,29 & $-8,0$ \\
\hline QDK & 391,423 & $-2,9814$ & $12^{*}$ & $7^{*}$ & 0,60 & 0,37 & $-6,8$ \\
\hline QPK & 373,452 & $-1,5429$ & 10 & 5 & 0,69 & 0,37 & $-7,8$ \\
\hline Lisinopril & 405,493 & $-3,9234$ & 8 & 5 & 0,91 & 0,39 & $-8,3$ \\
\hline
\end{tabular}

Keterangan : ${ }^{*}=$ menunjukkan pelanggaran atas kriteria Ro5
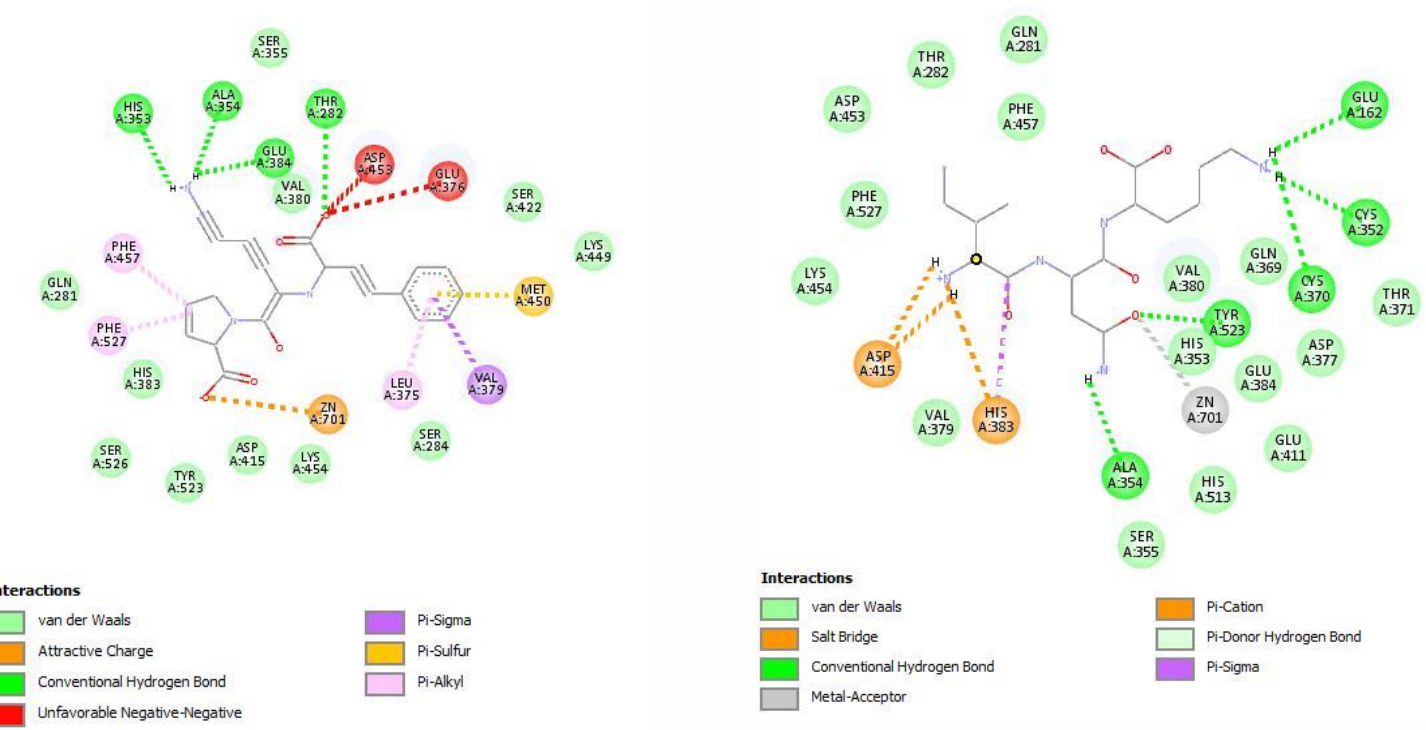

Figur 2. Skema dua dimensi interaksi antara residu asam amino peptida INK (kanan) dan lisiopril (kiri) dengan ACE.
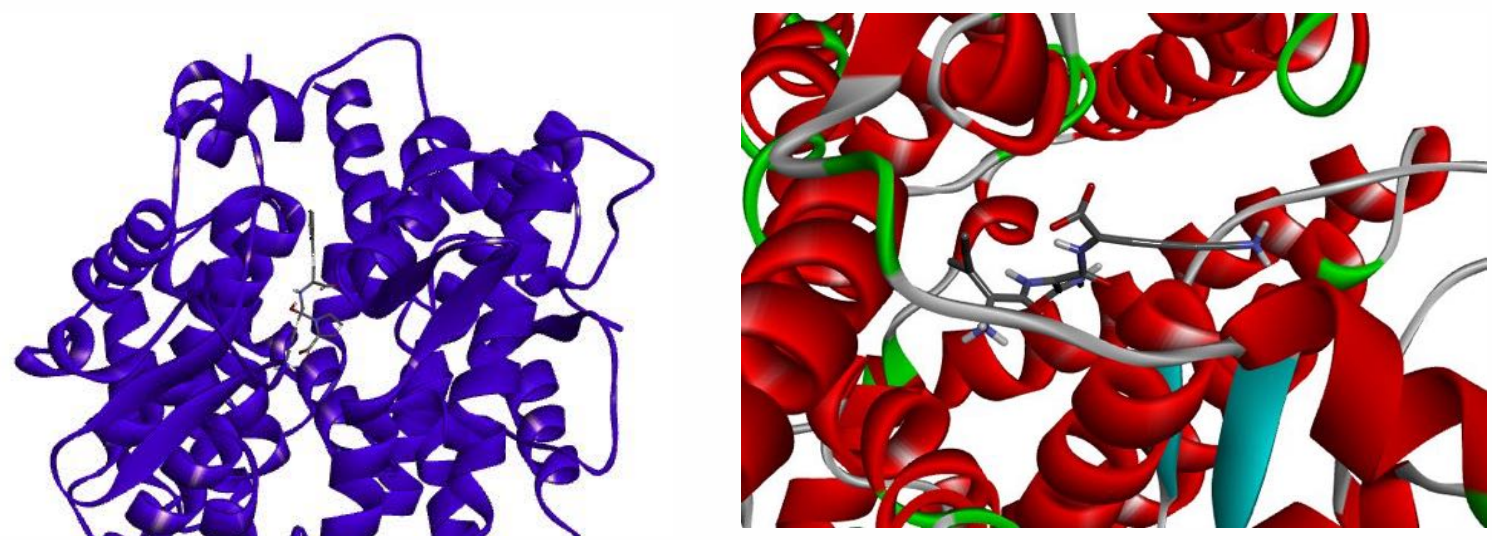

Figur 3. Grafis tiga dimensi posisi docking peptida INK (kanan) dan lisinopril (kiri).

Parameter Ro5, Bioaktivitas dan Energi Afinitas

Principal Component Analysis menunjukkan beberapa peptida yang memiliki kesamaan dengan lisinopril (Figur 1) yang kemudian dipilih untuk dilakukan proses docking. Walaupun demikian beberapa peptida terpilih dinilai melanggar Ro5, diantaranya ETM, INK, PVEP dan QDK (Tabel 3). Kriteria dari Ro5 yakni berat molekul tidak melebihi 500Da menunjukkan hasil bahwa seluruh peptida tidak melanggar kriteria tersebut. Nilai LogP tidak lebih besar dari 5 dan semua peptida tidak melanggar kriteria tersebut. Kriteria jumlah akseptor hidrogen tidak lebih dari 10 dilanggar oleh peptida PVEP dan QDK. Jumlah donor hidrogen tidak lebih dari 5 dilanggar oleh ETM, INK dan QDK. Fragmen peptida QDK dinilai paling menyalahi kaidah Ro5, sehingga prioritasnya diturunkan sebagai pilihan peptida bioaktif. Fungsi dari Ro5 yakni untuk menentukan apakah suatu obat dapat dimanfaatkan tubuh dari segi absorpsi, distribusi, metabolisme dan ekskresi (ADME) (Benet et al., 2016). Pelanggaran dua atau lebih kriteria Ro5 dinilai dapat menurunkan nilai kemanfaatan di dalam tubuh, walaupun demikian bukan berarti tidak dapat digunakan sebagai molekul terapeutik. Jedhe and Sanjayan (2017) berpendapat bahwa penggunaan Ro5 untuk molekul 
kecil dapat lebih longgar dalam kasus bahan obat berbasis peptida.

Nilai dari parameter bioaktivitas dapat digunakan untuk mengetahui sebesar apa suatu molekul dapat mempengaruhi mekanisme biologis. Nilai parameter yang semakin tinggi dapat menggambarkan semakin tinggi pula kemungkinan bioaktivitasnya (Husain et al, 2016). Hasil menunjukkan bahwa bioaktivitas protease inhibitor tertinggi pada kontrol positif yakni lisinopril. Peptida PVEP dan GVPK memiliki nilai tertinggi dibanding peptida lainnya, sehingga dapat diartikan bahwa kedua peptida tersebut memiliki kemampuan menghambat aktivitas protease tertinggi walaupun masih di bawah lisinopril. Bioaktivitas enyzme inhibitor tertinggi pada peptida ETM, sehingga terdapat kemungkinan peptida tersebut menghambat kinerja suatu enzim lebih kuat daripada peptida yang lain.

\section{Simulasi Docking}

Nilai afinitas energi terendah yang dihitung melalui simulasi docking terdapat pada lisinopril dan selanjutnya peptida INK (Tabel 3). Peptida INK memiliki nilai afinitas energi paling rendah daripada peptida yang lain. Semakin rendah nilai energi menandakan semakin kuat ikatan kompleks antara ligan dan reseptor (Kim and Skolnick, 2008). Hal tersebut menunjukkan bahwa INK menjadi peptida bioaktif yang mampu menambat pada ACE serta memiliki sifat protease inhibitor yang cukup tinggi, walaupun melanggar salah satu kriteria Ro5. Hal tersebut menjadikan peptida INK dinilai paling mampu menghambat kinerja ACE selain peptida lain di samping lisinopril. Fragmen peptida lain dari kasein $\beta$ yang memiliki kemampuan ACEi yakni VPP, IPP dan SKYVP, namun perlu proses fermentasi untuk mendapatkan peptida tersebut (Iwaniak et al., 2014). Konsumsi obat sintetis ACEi seperti halnya lisinopril ternyata memberikan efek samping berupa batuk, pusing dan edema angioneurotik (Muhammad and Fatima, 2015). Hal tersebut memberikan keuntungan bagi peptida INK melalui konsumsi susu kambing sebagai alternatif pengganti lisinopril. Wijesekara and Kim (2010) menambahkan bahwa peptida bioaktif cenderung tidak menghasilkan efek samping dibanding obat sintetis ACEi.

Fragmen INK merupakan hasil dari hidrolisis kasein $\beta$ pada semua alel yakni $A, C, D$ dan $E$ atau polimorfisme tidak berpengaruh dalam menghasilkan peptida bioaktif berbeda. Polimorfisme menyebabkan perbedaan pada fragmen peptida, namun tidak memiliki karakteristik sebagai peptida bioaktif. Contoh yang terjadi yakni dihasilkan peptida AVPQR dari alel A dan $E$ serta VVPQR dari alel C dan D. Fragmen unik lain yakni SQPK pada alel $A, C$ dan $D$, namun alel $E$ menghasilkan fragmen SQ. Hal tersebut menunjukkan bahwa polimorfisme kasein $\beta$ tidak memberikan dampak pada produksi peptida bioaktif.

Peptida bioaktif INK sebagai ligan dapat berinteraksi dengan ACE sebagai reseptor pada simulasi docking. Interaksi non kovalen seperti halnya ikatan hidrogen, ikatan halogen, ikatan Van der Waals, Pi-Pi stacking, interaksi hidrofilik dan hidrofobik menjadi komponen yang signifikan dalam mengatur konformasi peptida bahkan hubungan antara ligan dan reseptor. Asam amino yang memiliki muatan elektrik memiliki pengaruh dalam proses biologis karena kemampuannya untuk menstabilkan kompleks ligan-reseptor melalui interaksi elektrostatis (Jedhe and Sanjayan, 2017). Asam amino lisin $(\mathrm{K})$ pada peptida INK memiliki muatan positif yang dapat memberikan interaksi dengan asam amino bermuatan negatif. Skema dua dimensi interaksi antara ligan INK (Ile-Asp-Lys) menunjukkan bahwa terdapat beberapa jenis interaksi diantaranya ikatan hidrogen pada gugus $R$ asam amino Lys ligan dengan asam amino Glu162, Cys352 dan Cys370 dari ACE serta ujung $\mathrm{N}$ asam amino lle ligan dengan Asp415 dan His383 dari ACE; ikatan metal Zn701 serta hidrogen oleh Ala354 dari ACE pada gugus $R$ asam amino Asp ligan. Penjelasan tersebut digambarkan pada Figur 2 dan 3. Lebih beragamnya ikatan lisinopril dengan residu asam amino pada ACE dapat menjadi salah satu penyebab afinitas energi lebih rendah dibanding peptida INK (Hermanto, 2016).

\section{Kesimpulan}

Berdasarkan hasil yang diperoleh dapat disimpulkan bahwa kasein $\beta$ susu kambing jika dicerna dengan enzim pencernaan dapat menghasilkan peptida bioaktif ACEi yakni INK yang menghambat kinerja ACE, namun tidak sebaik lisinopril. Polimorfisme kasein $\beta$ tidak menyebabkan perbedaan produksi peptida bioaktif.

\section{Daftar Pustaka}

Benet, L.Z., Hosey, C.M., Ursu, O., Oprea, T.I. 2016. BDDCS, the rule of 5 and drugability. Advanced Drug Delivery Reviews 101(1): 89-98. DOI: 10.1016/j.addr.2016.05.007

Caroli, A., Chiatti, F., Chessa, S., Rignanese, D., Bolla, P., Pagnacco, G. 2006. Focusing on the goat casein complex. Journal of Dairy Science 89:3178-3187. DOI: 10.3168/jds.S0022-0302(06) $72592-9$

Gao, H.N., Zhao, S.G., Zheng, N., Zhang, Y.D., Wang, S.S., Zhou, X.Q., Wang, J.Q. 2017. Combination of histidine, lysine, methionine, and leucine promotes $\beta$-casein synthesis via the mechanistic target of rapamycin signaling pathway in bovine mammary epithelial cells. Journal of Dairy Science 100(9): 7696-7709. DOI: 10.3168/jds.2015-10729

Haque, E., Chand, R. 2008. Antihypertensive and antimicrobial bioactive peptides from milk proteins. European Food Research Technology 227(1): 7-15. DOI: 10.1007/s00217-007-0689-6

Hermanto, S. 2016. Virtual screening peptida bioaktif antihipertensi dari hidrolisat kasein susu kambing etawa. Alchemy: Journal of Chemistry 5(2): 45-54. DOI: 10.18860/al.v5i2.3671

Husain, A., Ahmad, A., Khan, S.A., Asif, M., Bhutani, R., Al-Abbasi, F.A. 2016. Synthesis, molecular properties, toxicity, and biological evaluation of some new substituted imidazolidine derivatives in search of potent anti-inflammatory agents. Saudi 
Pharmaceutical Journal 24(1): 104-114. DOI: 10.1016/j.jsps.2015.02.008

Iwaniak, A., Minkiewicz, P., Darewicz, M.. 2014. Foodoriginating ACE inhibitors, including antihypertensive peptides, as preventive food components in blood pressure reduction. Comprehensive Reviews in Food Science and Food Safety 13(2): 144-134. DOI: 10.1111/15414337.12051

Jedhe, G.S., Sanjayan, G.J. 2017. Chapter 6 - Structural Design for Bioactive Peptides in Peptide-based Drug Discovery : Challenges and New Therapeutics. Srivastava, V. (ed.). Royal Society of Chemistry, London. DOI: 10.1039/ 9781788011532-00172

Johnston, N., Dettmar, P.W., Bishwokarma, B., Lively, M.O., Koufman, J.A. 2007. Activity/stability of human pepsin: implications for reflux attributed laryngeal disease. The Laryngoscope. 117 (6): 1036-9. DOI: 10.1097/MLG.0b013e31804154c3

Kaminski, S., Cieslinska, A., Kostyra, E. 2007. Polymorphism of bovine beta-casein and its potential effect on human health. Journal of Applied Genetics 48(3): 189-198. DOI: 10.1007/BF03195213

Kim, R., Skolnick, J. 2008. Assesment of programs for ligand binding affinity prediction. Journal of Computational Chemistry 29(8): 1316-1331. DOI: 10.1002/jcc.20893

Lee, K.J., Kim, S.B., Ryu, J.S., Shin, H.S., Lim, J.W. 2005. Separation and purification of angiotensin converting enzyme inhibitory peptides derived from goat's milk casein hydrolysates. AsianAustralasian Journal of Animal Science 18(5): 741-746. DOI: 10.5713/ajas.2005.741

Marletta, D., Criscione, A., Bordonaro, S., Guastella, A.M., D'Urso, G. 2007. Casein polymorphism in goat's milk (Review). Lait 87: 491-504. DOI: 10.1051/lait:2007034

Morris, G.M., Huey, R., Olson, A.J. 2008. Using AutoDock for ligand-receptor docking. Current Protocols in Bioinformatics 24 (8): 8.14.1-8.14.40. DOI: 10.1002/0471250953.bi0814s24

Muhammad, S.A., Fatima, N. 2015. In silico analysis and molecular docking studies of potential angiotensin-converting enzyme inhibitor using quercetin glycosides. Pharmacognosy Magazine
11(42): 123-126. DOI: 10.4103/0973-1296. 157712

Năsalean, A., Ognean, L., Muntean, S., Bâlici, Ş., Matei, H. 2017. Comparative analysis of electrophoretic profile of major proteins of milk from Alpine and Carpathian goats. Bulletin UASVM Veterinary Medicine 74(1): 20-25. DOI:10.15835/buasvmcnvm:12447

Park., Y.W., Juárez, M., Ramos, M., Haenlein, G.F.W. 2007. Physico-chemical characteristics of goat and sheep milk. Small Rumuminant Research 68(1-2): 88-113. DOI: 10.1016/j.smallrumres. 2006.09.013

Petrat-Melin, B., Andersen, P., Rasmussen, J.T., Poulsen, N.A., Larsen, L.B. Young, J.F. 2015. In vitro digestion of purified $\beta$-casein variants $A 1$, $A 2, B$, and $\mathrm{I}$ : effects on antioxidant and angiotensin-converting enzyme inhibitory capacity. Journal of Dairy Science 98: 15-26. DOI: 10.3168/jds.2014-8330

Rahajeng, E., Tuminah, S. 2009. Pervalensi hipertensi dan determinannya di Indonesia. Majalah Kedokteran Indonesia 59(12): 580-587.

Rodriguez, J., Gupta, N., Smith, R.D., Peyzner, P.A. 2008. Does trypsin cut before proline?. Journal of Proteome Research. 7 (1): 300-305. DOI: 10.1021/pr0705035

Salem, S.A., El-Agamy, E.I., Salama, F.A., Abo-Soliman, N.H. 2009. Short note : Isolation, molecular and biochemical characterization of goat milk casein and its fraction. Tropical and Subtropical Agrosystems 11(1): 29-35.

Wang, Z., Zhang, S., Wang, W., Feng, F., Shan, W. 2011. A novel Angiotensin I Converting Enzyme inhibitory peptide from the milk casein: virtual screening and docking studies. Agricultural Sciences in China 10(3): 463-467. DOI: 10.1016/S1671-2927(11)60026-6

Weimann, C., Meisel, H., Erhardt, G. 2009. Short communication: bovine $\mathrm{K}$-casein result in different angiotensin I converting enzyme (ACE) inhibitory peptides. Journal of Dairy Science 92:1885-1888. DOI:10.3168/jds.2008-1671

Wijesekara, I., S. Kim. 2010. Angiotensin-I-Converting Enzyme (ACE) inhibitors from marine resources: prospects in the pharmaceutical industry. Marine Drugs 8(4): 1080-1093. DOI:10.3390/md8041080 